\title{
Evaluasi Program Indonesia Pintar \\ Pada Dinas Pendidikan Dan Kebudayaan Kota Baubau Tahun 2017
}

\author{
Hartini Zahimu \\ Universitas Muhammadiyah Buton \\ Email: tini.zh77@gmail.com
}

\begin{abstract}
Abstrak, Penelitian ini bertujuan untuk mengetahui evaluasi Program Indonesia Pintar di lingkup Dinas Pendidikan dan Kebudayaan Kota Baubau tahun 2017 dan untuk mengetahui apakah ada hambatan yang ditemukan dalam pelaksanaan programIndonesia Pintar pada Dinas Pendidikan dan Kebudayaan Kota Baubau tahun 2017. Populasi dalam penelitian ini adalah Penerima Program Indonesia Pintar tahun 2017, sedangkan Sampel yang digunakan pada penelitian ini yaitu data pada instansi Dinas Pendidikan dan Kebudayaan Kota Baubau tahun 2017, Jenis data Data Kuantitatif dan Data kualitatif, yaitu Analisis yang digunakan pada penelitian ini adalah Analisis Deskriptif Kualitatif. (3) Berdasarkan hasil penelitian bahwa pelaksanaan Program Indonesia Pintar pada Dinas Pendidikan dan Kebudayaan Kota Baubau tahun 2017, terdapat 9.413 penerima PIP, terdapat sebanyak 8.456 telah tersalurkan, serta sebanyak 957 penerima PIP yang dana nya dikembalikan ke pusat (Pemerintah Pusat) dikarenakan telah meninggal dunia, sudah tidak aktif di Sekolah dan siswa/siswi tersebut telah pindah sekolah.
\end{abstract}

Kata Kunci : Evaluasi, Program Indonesia Pintar 


\section{Pendahuluan}

Sektor pendidikan memiliki peranan yang sangat strategis dalam menunjang tercapainya pembangunan nasional, terutama dalam pengembangan sumber daya manusia yang merupakan faktor penentu dalam pembangunan. Manusia yang pada dasarnya merupakan pusat dari pembangunan memiliki andil yang sangat besar dalam mewujudkan pembangunan tersebut. Hal tersebut sejalan dengan prioritas dan sasaran pembangunan nasional Indonesia tahun 2017 dalam dimensi pembangunan manusia yaitu dengan pembangunan pendidikan.

Pendidikan sebagaimana dikemukakan oleh Rutz (dalam Sindhunata, 2001) bahwa pendidikan berawal dari fakta bahwa manusia mempunyai kekurangan, atau dalam bahasanya disebut defisit, karenanya pendidikan merupakan jawaban untuk membuatnya lengkap dan sejalan dengan hal tersebut. Pendidikan berarti sebuah proses belajar yang ditunjukkan untuk membangun manusia dengan pengetahuan dan keterampilan. Pendidikan yang berkualitas akan menjadi pondasi yang kuat bagi suatu bangsa untuk menghadapi berbagai tantangan di masa mendatang, seperti persaingan global yang kian meningkat. Hal tersebut menyadarkan negara berkembang untuk semakin memperhatikan kualitas pendidikannya dan mengatasi permasalahan pendidikan, tak terkecuali negara Indonesia.

Pendidikan di Indonesia saat ini masih dikatakan rendah jika dibandingkan dengan negara lain. Hal ini terbukti dari peringkat Indonesia yang menduduki peringkat ke 69 dari 127 negara di dunia, data tersebut berdasarkan data dalam Education For All (EFA) Global Monitoring Report 2011 yang dirilis oleh UNESCO di New York (http://berita-160-kualitas-pendidikan-indonesia-ranking-69-tingkat-dunia.html, diakses pada 24 Agustus 2017).

Permasalahan lainnya yang dihadapi ialah tingginya angka anak putus sekolah. Berdasarkan data Kementerian dan Kebudayaan pada tahun 2016 terdapat lebih dari satu juta anak putus sekolah pada jenjang Sekolah Dasar (SD) dan tak melanjutkan ke tingkat Sekolah Menengah Pertama (SMP). Jika digabungkan antara yang tidak tamat SD-SMP, maka ada sekitar 4,3 juta anak yang tak mengenyam pendidikan dasar. Menurut ketua pengurus Tanoto Foundation, Sihol Sihombing bahwa persoalan mendesak yang harus diperbaiki dari pendidikan saat ini adalah akses kualitas pendidikan tersebut. 
(Kompas.com,http://amp.kompas.com/edukasi/read/2017/08/18/06490021/72-

tahun-merdekaapa -kabar pen didikan-indoensia, diakses pada 24 Agustus 2017).

Pendidikan yang berkualitas menjadi impian semua masyarakat, namun tak semua lapisan masyarakat dapat mengenyam pendidikan yang berkualitas dikarenakan faktor kemiskinan. Pendidikan dan kemiskinan memiliki hubungan yang saling mempengaruhi. Pandangan tentang tingkat pendidikan akan mempengaruh peningkatan kualitas kehidupan masyarakat membuat semua orang memerlukan pendidikan. Masalah pembiayaan pendidikan telah menjadi masalah yang krusial bagi masyarakat, terutama masyarakat dengan kategori menengah kebawah. Mahalnya biaya pendidikan sering kali menjadi penghambat masyarakat kecil dalam menjangkau pendidikan yang tinggi. Disamping biaya pendidikan ada juga biaya perlengkapan yang juga memberatkan para orang tua dalam memenuhi kebutuhan pendidikan. Sudah menjadi tanggung jawab pemerintah Indonesia dalam memberikan pelayanan pendidikan yang berkualitas kepada warga negara.

Pemerintah memiliki kewajiban untuk memenuhi hak setiap warga negara dalam memberikan layanan pendidikan yang berguna untuk peningkatan kualitas hidup bangsa Indonesia. Sebagaimana yang telah diamanatkan dalam pembukaan UndangUndang Dasar 1945 alinea ke empat yaitu untuk mencerdaskan kehidupan bangsa. Pemerintah Indonesia secara formal telah melakukan upaya untuk pemerataan pendidikan dan pemberian akses layanan pendidikan. Mulai dari Sekolah Dasar hingga Sekolah Menengah, dilanjutkan dengan wajib belajar pendidikan selama sembilan tahun. Itu berarti bahwa semua warga negara Indonesia berhak untuk mendapatkan pendidikan dan pengajaran tanpa terkecuali, baik untuk orang kaya maupun orang miskin dan masyarakat perkotaan maupun masyarakat pedesaan.

Untuk mengatasi permasalahan pendidikan di Indonesia pemerintah telah mengupayakan berbagai program-program yang bertujuan untuk pembangunan pendidikan. Dimulai dari program dana Bantuan Operasional Sekolah (BOS) yang bertujuan untuk menyediakan pendanaan biaya operasional sekolah bagi satuan pendidikan dasar sebagai penunjang program wajib belajar, hal ini dilakukan untuk menunjang masyarakat untuk mengakses pendidikan, khususnya masyarakat miskin. Selain itu, ada juga program-program Bantuan Siswa Miskin (BSM) untuk membantu masyarakat miskin dalam membiayai pendidikan yang sedang ditempuh. 
Upaya untuk pembangunan manusia melalui pendidikan masih terus ditingkatkan pemerintah. Pemerintah memiliki komitmen untuk terus meningkatkan akses masyarakat miskin/tidak mampu dalam mendapatkan pendidikan. Begitu pula pemerintahan presiden Joko Widodo dan wakil presiden Jusuf Kalla yang mengeluarkan kebijakan untuk pembangunan manusia melalui program berbasis pendidikan. Program Indonesia Pintar (PIP) merupakan program prioritas Presiden Joko Widodo, yang dirancang khusus untuk membantu anak dari keluarga miskin/tidak mampu agar tetap mendapatkan layanan pendidikan sampai tamat pendidikan menengah/sederajat. Selain itu, PIP ditujukan untuk membantu meringankan biaya personal pendidikan, mencegah agar siswa tidak putus sekolah, serta mendorong siswa putus sekolah dapat melanjutkan pendidikan di satuan pendidikan formal maupun non formal (Petunjuk Teknis Program Indonesia Pintar Tahun 2017).

Program Indonesia Pintar yang diwujudkan dengan pemberian Kartu Indonesia Pintar ini dimulai sejak akhir tahun 2014 sebagai pengganti Bantuan Siswa Miskin (BSM) dengan bekerja sama dengan Kementrian Pendidikan Dan Kebudayaan (Kemendikbud), Kementrian Sosial (Kemensos) dan Kementrian Agama (Kemenag). Melalui program ini pemerintah berupanya mengedepankan pendidikan karena mengingat bahwa kualitas sumber daya manusia sangat mempengaruhi kemajuan bangsa ini. Untuk itu pemerintah berupaya selalu memberikan pelayanan prima kepada masyarakat khususnya masyarakat yang dikategori miskin/kurang mampu. Melalui program Kartu Indonesia Pintar ini juga pemerintah berharap akan terciptanya pemerataan pendidikan dan tidak akan ada lagi yang namanya kesenjangan pendidikan dan berharap semua lapisan masyarakat dapat merasakan pendidikan yang berkualitas tanpa pandang buluh (Kemendikbud, http://indonesiapintar.kemdikbud.go.id/, diakses pada 29 Agustus 2017).

Tujuan utama dari Program ini adalah untuk membantu siswa miskin agar memperoleh pendidikan yang layak, mencegah anak putus sekolah, serta memenuhi kebutuhan sekolah mereka. Dengan ditetapkannya tujuan tersebut diharapkan dapat meningkatkan pendidikan di Indonesia dan pemerataan pendidikan yang akan berpengaruh terhadap tingkat pembangunan di Indonesia. Presiden Joko Widodo mengatakan bahwa manfaat dari program KIP ini terus dapat dirasakan oleh pelajar yang ada di Indonesia dan pada tahun 2017 sasaran KIP akan diperluas lagi di setiap daerah, bukan hanya untuk siswa yang kurang mampu, tapi juga siswa yatim piatu, agar 
mereka

mendapat

pendidikan

layak.

(Kompas.com,http://nasional.kompas.com/read/2017/01/29/17194701/jokowi.Manfa at.kartu.indonesia.pintar.terus.dirasakan.pelajar, diakses pada 29 Agustus 2017).

Namun tidak dapat dipungkiri bahwa dalam setiap pelaksanaan program memiliki kendala-kendala ataupun masalah yang menghambat program tersebut mencapai sasarannya. Masalah yang paling krusial dari sebuah program biasanya tidak tepat sasaran dan menjangkau semua target group yang telah ditentukan awalnya. Semenjak program ini diluncurkan banyak kendala yang dihadapi dalam pelaksanaan KIP di Indonesia. Seperti halnya program KIP yang belum dapat menjangkau seluruh anak dari keluarga miskin. Dari data yang didapat menunjukkan bahwa 2,9 juta anak di tanah air belum terjangkau layanan program ini dan berstatus putus sekolah atau tidak bersekolah lagi. Mencermati kondisi tersebut, yang telah diuraikan di atas maka penulis tertarik untuk mengetahui bagaimana Evaluasi program Kartu Indonesia Pintar pada Jenjang Pendidikan Dasar (SD) pada Dinas Pendidikan dan Kebudayaan Kota Baubau yang dihadapi pemerintah dalam mendapatkan akses pelayanan Kartu Indonesia Pintar tersebut.

\section{Metode Penelitian}

Penelitian ini menggunakan jenis penelitian evaluasi dengan menggunakan model evaluasi berbasis kebijakan (good oriented evolution) yang menentukan tujuan dari program yang sudah ditetapkan jauh sebelum program dimulai, yang dilakukan berkesinambungan, terus menerus, mengecek sejauh mana tujuan tersebut sudah terlaksana di dalam proses pelaksanaan program. Sampel untuk menunjang penelitian ini data penerima PIP yang bersumber dari Dinas Pendidikan dan Kebudayaan Kota Baubau tahun 2017 yaitu pegawai instansi Dinas Pendidikan dan Kebudayaan Kota Baubau yang menangani Program Indonesia Pintar yaitu 3 orang pegawai Dinas Pendidikan dan Kebudayaan Kota Baubau. Data yang diperlukan dalam penelitian ini dibedakan menjadi dua yakni sumber data primer dan sumber data sekunder. Data yang diperoleh dalam penelitian ini adalah data yang bersifat kualitatif, maka analisis data yang digunakan non statistik.

\section{Pembahasan}

Implementasi Program Indonesia Pintar (PIP) Kota Baubau Tahun 2017 
Program Indonesia Pintar (PIP) adalah program bantuan pendidikan bagi siswa/siswi yang tidak mampu agar dapat melanjutkan pendidikannya tanpa ada kendala. Sebagaimana hasil kutipan wawancara penulis bersama Wa Ida, S.Pd selaku Kepala bagian Perencanaan Program Dinas Pendidikan dan Kebudayaan Kota Baubau, beliau sejak awal adanya program bantuan pendidikan sampai dengan sekarang bernama PIP yang bertugas memfasilitasi program PIP tersebut.

Program PIP adalah bantuan untuk siswa yang tidak mampu, sebelum adanya Program Indonesia Pintar, program bantuan pemerintah itu bernama BSM (Bantuan Siswa Miskin), dimana Program Indonesia Pintar ini adalah penyempurnaan dari Program BSM tersebut. Kami sebagai fasilitasi program tersebut dan selalu berkoordinasi dengan pihak sekolah penerima PIP, agar tidak terjadi kendala dalam pelaksaannya, dan pelaksaaan Program Indonesia Pintar ini telah terlaksana sesua ketentuan petunjuk teknis pelaksaan Program Indonesia Pintar tahun 2017.

Berdasarkan hasil wawancara juga dapat disimpulkan bahwa Program Indonesia Pintar pertama diluncurkan pada tahun 2014 dengan nama BSM (Bantuan Siswa Miskin), program ini diperuntukan pada siswa miskin yang tidak mampu dalam hal ekonomi untuk memenuhi kebutuhan sekolahnya, seperti membeli seragam sekolah, buku, sepatu dan lain-lain, agar siswa/siswi yang tidak mampu tersebut tidak memberatkan orang tua dalam membeli perlengkapan sekolah.

Dalam kebijakan publik, seperti yang dikemukakan oleh Wirawan (2012:7), bahwa mengemukakan evaluasi merupakan riset untuk mengumpulkan, menganalisis, dan menyajikan informasi yang bermanfaat mengenai objek evaluasi, menilai dengan membandingkannya dengan indikator evaluasi dan hasilnya dipergunakan untuk mengambil keputusan mengenai objek evaluasi. Evaluasi sebagai proses usaha untuk mengumpulkan informasi yang dapat digunakan sebagai bahan pertimbangan untuk membuat keputusan. Evaluasi harus dilakukan secara berkala dan terus-menerus agar mengetahui kualitasnya.

Program PIP adalah bantuan untuk siswa yang tidak mampu, sebelum adanya Program Indonesia Pintar, program bantuan pemerintah itu bernama BSM (Bantuan Siswa Miskin), dimana Program Indonesia Pintar ini adalah penyempurnaan dari Program BSM tersebut. Dinas Pendidikan dan Kebudayaan Sebagai Fasilitator Program Indonesia Pintar telah berjalan dengan baik sesuai aturan yang berlaku, dimana siswa penerima PIP tersebt telah memanfaatkan dana tersebut untuk keperlan sekolah. Kami 
harap Program ini akan terus dilaksanakan agar anak anak Sekolah khususnya di Kota Baubau dapat terbantu dengan adanya program ini.

Berdasarkan hasil wawancara di atas dapat disimpulkan bahwa proses pelaksanaan Program Indonesia Pintar di Dinas Pendidikan dan Kebudayaan Kota Baubau sudah sesuai dengan petunjuk teknis yang merupakan standar dasar dan acuan dalam pelaksanaan PIP dan telah sesuai dengan perundang-undangan yang berlaku. Sejalan dengan itu, menurut Kartasasmita yang dikutip oleh Widodo (2006:189) mengatakan bahwa, kebijakan merupakan untuk memahami dan mengartikan (1) apayang dilakukan oleh pemerintah mengenai suatu masalah, (2) apa yang menyebabkan mempengaruhinya, (3) apa pengaruh dan dampak dari suatu kebijakan tersebut.

Menurut Carl Friedrich dalam Wahab, (2005:3) merumuskan pendapatnya bahwa, kebijakan adalah suatu tindakan yang mengarah pada tujuan yang diusulkan oleh seseorang, kelompok, atau pemerintah dalam lingkungan tertentu sehubungan dengan adanya hambatan tertentu seraya mencari peluang-peluang untuk mencapai tujuan atau mewujudkan sasaran yang diinginkan. Selanjutnya menurut Anderson yang dikutip oleh Wahab (2005:2) menyatakan bahwa, Kebijakan sebagai perilaku dari sejumlah aktor (pejabat,kelompok, instansi pemerintah) atau serangkaian aktor dalamsuatu bidang kegiatan tertentu, dalam tindakan-tindakan atau kegiatankegiatan pemerintah serta perilaku negara pada umumnya.

Adapun rekapan data penerima PIP tahun 2017 pada bidang Pendidikan Dasar yaitu terdapat Penerima Program Indonesia Pintar pada Dinas Pendidikan dan Kebudayaan Kota Baubau tahun 2017. Data Pencairan Program Indonesia Pintar pada tahun 2017 terdapat 9.413 siswa/siswi dari jumlah tersebut terdapat 8.456 yang telah cair dan telah diterima oleh penerima PIP, selisihnya terdapat 957 yang dananya ditarik kembali oleh pusat, dikarenakan berbagai alasan yaitu :

1. Siswa sudah tidak aktif/Pindah Sekolah

2. Siswa meninggal dunia

3. Siswa sudah bukan dikategorikan siswa miskin

Berdasarkan hasil wawancara di atas, Penerima Program Indonesia Pintar pada Dinas Pendidikan dan Kebudayaan Kota Baubau tahun 2017. Data Pencairan Program Indonesia Pintar pada tahun 2017 terdapat 9.413 siswa/siswi dari jumlah tersebut 
terdapat 8.456 yang telah cair dan telah diterima oleh penerima PIP, selisihnya terdapat 957 yang dananya ditarik kembali oleh pusat, dikarenakan berbagai alasan yaitu :

1. Siswa sudah tidak aktif/Pindah Sekolah

2. Siswa meninggal dunia

3. Siswa sudah bukan dikategorikan siswa miskin

Hal itu berdasarkan hasil penelitian yang berasal dari sumber data berupa kuesioner, wawancara dan dokumentasi pada Dinas Pendidikan dan Kebudayaan Kota Baubau bahwa siswa penerima PIP yaitu siswa yang mempunyai KIP dan KPS, dan pelaksanaan program Indonesia pintar telah sesuai dengan ketentuan yang berlaku. Dampak dari PIP yaitu berkurangnya siswa/siswi yang putus sekolah karena terkendala oleh biaya sekolah yang terlalu mahal.

\section{Kesimpulan}

Berdasarkan pembahasan sebelumnya, Program Indonesia Pintar adalah untuk membantu siswa miskin agar memperoleh pendidikan yang layak, mencegah anak putus sekolah, serta memenuhi kebutuhan sekolah mereka. Dengan ditetapkannya tujuan tersebut diharapkan dapat meningkatkan pendidikan di Indonesia dan pemerataan pendidikan yang akan berpengaruh terhadap tingkat pembangunan di Indonesia. Presiden Joko Widodo mengatakan bahwa manfaat dari program KIP ini terus dapat dirasakan oleh pelajar yang ada di Indonesia dan pada tahun 2017 sasaran KIP akan diperluas lagi di setiap daerah, bukan hanya untuk siswa yang kurang mampu, tapi juga siswa yatim piatu, agar mereka mendapat pendidikan layak

Model evaluasi yang digunakan yaitu model evaluasi berbasis kebijakan yang dikembangkan oleh tyler dimana evaluasi dilakukan terus menerus, berkesinambungan, mengecek sejauh mana tujuan tersebut terlaksana didalam proses pelaksanaan program. Maka dari itu tujuan dari program PIP ini adalah untuk membantu siswa/siswi miskin agar dapat bersekolah kembali dan akan berdampak pada kurangnya pelajar putus sekolah dikarenakan biaya sekolah yang terlalu mahal. Berdasarkan tipe tersebut maka Program Indonesia Pintar adalah program bantuan pendidikan untuk siswa/siswi tidak mampu jenjang Pendidikan Dasar (SD \&SMP), serta menjadi acuan atau evaluasi untuk PIP tahun berikutnya.Program Indonesia Pintar pada Dinas Pendidikan dan Kebudayaan 
Kota Baubau telah dilaksanakana sesuai aturan perundang-undangan yang berlaku (sesuai juknis PIP tahun 2017) serta menjadi acuan untuk program Indonesia Pintar pada tahun berikutnya.

\section{Daftar Pustaka}

Agustiono, Leo. 2008. Dasar-Dasar Kebijakan Publik. Bandung: Alfabeta.

A Partanto, Pius. 1994. Kamus Ilmiah Populer. Arkola.Surabaya:

Achmadi dan Narbuko 2004. Metode Penelitian. Bumi Aksara.Jakarta

Danim, Sudarwan. 2002. Menjadi Peneliti kualitatif. Pustaka Setia. Bandung

Dillon H.S dan Hermanto, 1993, Kemiskinan di Negara Berkembang Masalah Krusial Global, LP3ES, Jakarta.

Dunn, Willam. 2000. Pengantar Analisis Kebijakan Publik, Edisis Ke-2. Yogyakarta : Gajah Mada University Press

Edward, George. C.1980. Implementing Public Policy. Washington D.C: Congressional Quarterly Inc

Ekowati, Lilik. 2005. Perencanaan, ImplementasidanEvaluasiatau Program. Surakarta :PustakaCakra.

Fahriani, Isni. 2006. Prinsip-PrinsipPerumusanKebijakan Negara. Jakarta: BumiAksara

Kementerian Pendidikan Republik Indonesia, 2015, Kamus Besar Bahasa Indonesia, Edisi kedua, cetakan ketujuh Balai Pustaka, Jakarta.

Moleong, Lexy J. 2005. Metode Penelitian Kualitatif. PT.Remaja Rosdakarya. Bandung

Miles, B. Mathew dan Michael Huberman. 2002. Analisis Data Kualitatif Buku Sumber Tentang Metode-metode Baru. UIP.Jakarta.

Muhammad dan Ridwan Mas'ud, 2005, Zakat dan Kemiskinan: Instrumen pemberdayaan ekonomi umat, UII Press, Yogyakarta.

Nugroho, Riant. 2008. KebijakanPublik, Formulasi, Implementasi, danEvaluasi. Jakarta: PT Elex Media Komputindo.

Parsudi Suparlan, 1993, Kemiskinan di Perkotaan, Yayasan Obor Indonesia, Jakarta.

Peraturan menteri pendidikan dan kebudayaan Republik indonesia Nomor 9 tahun 2018 Tentang Perubahan atas peraturan menteri pendidikan dan kebudayaan Nomor 19 tahun 2016 tentang petunjuk teknis Program indonesia pintar.

Peraturan Pemerintah Nomor 48 Tahun 2008 tentang Pendanaan Pendidikan;

Peraturan Menteri Pendidikan dan Kebudayaan, Nomor: 07/D/BP/2017 dan Nomor : 02/MPK.C/PM/2017 Tentang PETUNJUK PELAKSANAAN (Juklak) PROGRAM INDONESIA PINTAR TAHUN 2017

Sajogyo dan Jiwati Sajogyo, 1983, Sosioogi Pedesaan, Gajahmada University Press, Yogyakarta.

Soekanto, Soejono, 2006, Sosiologi Suatu Pengantar,PT. Raja Grafindo Persada, Jakarta.

Sugiyono. 2011. Metode Penelitian Kuantitatif, Kualitatif dan R\&D. : AfabetaBandung

Thoha, Miftah. 2002. Dimensi-Dimensi Prima IlmuAdministrasi Negara. Jakarta: PT Raja GrafindoPersada

Undang-Undang Nomor 17 Tahun 2007 tentang Rencana Pembangunan Jangka Panjang Periode 2005-2025;

Undang-Undang Nomor 20 Tahun 2003 tentang Sistem Pendidikan Nasional

Wahab, 2008. Analisis Kebijaksanaan: dari Formulasi Ke Implementasi Kebijaksanaan Negara:Jakarta : Bumi Aksara. 
Wahab, Solichin Abdul. 2005. Analisis Kebijaksanaan: dari Formulasi Ke Implementasi Kebijaksanaan Negara: Edisii Ke Satu. Jakarta : Bumi Aksara.

Widodo, Joko. 2006. Analisis Kebijakan Publik, Konsep Dan Aplikasi Analisa Proses Analisis Kebijakan publik. Edisi Ke-1. Malang Bayumeda Publishing.

Widodo, Joko.2010. Analisis Kebijakan Publik. Malang: Bayumedia.

Winarno, Budi. 2005. Teori dan Proses Kebijakan Publik. Yogyakarta: Penerbit Media Pressindo (Anggota IKAPI). 